\title{
Endophytic fungi from Brachiaria grasses in Brazil and preliminary screening of
}

\section{Sclerotinia sclerotiorum antagonists}

\author{
Danielly de Souza Gama ${ }^{1}{ }^{\odot}$, ítalo Augusto Férrer Melo Santos ${ }^{1} \odot$, Lucas Magalhães de Abreu²๑, Flávio Henrique Vasconcelos de \\ Medeiros $^{3 \odot}$, Whasley Ferreira Duarte ${ }^{1 \odot}$, Patrícia Gomes Cardoso ${ }^{1 * \odot}$
}

\author{
UUniversidade Federal de Lavras - Depto. de Biologia, C.P. \\ 3037 - 37200-000 - Lavras, MG - Brasil. \\ 2Universidade Federal de Viçosa - Depto. de Fitopatologia - \\ Campus Universitário - 36570-977 - Viçosa, MG - Brasil. \\ ${ }^{3}$ Universidade Federal de Lavras - Depto. de Fitopatologia. \\ *Corresponding author < patricia@ufla.br>
}

Edited by: Fernando Dini Andreote

Received June 27, 2018

Accepted October 29, 2018
ABSTRACT: Fungal endophytes of Brachiaria, a nonhost of Sclerotinia sclerotiorum, may harbor species with antagonistic effects against this plant pathogen. The objective of this work was to investigate the diversity of endophytic fungi associated with different Brachiaria species and hybrids and evaluate their potential to inhibit the plant pathogen $S$. sclerotiorum. Stem samples from 39 Brachiaria spp. plants were collected in pasture fields and experimental areas of three states of Brazil resulting in 74 endophytes isolated. Twenty-eight species were identified by sequences of the Internal Transcribed Spacer (ITS) and 18S rDNA regions. Paraconiothyrium sp. was the most abundant endophyte, accounting for $24 \%$ (14 isolates) of total, and it was isolated from B. ruziziensis, B. decumbens, B. humidicola, and B. brizantha. Phoma sorghina was the second most abundant taxon, followed by Sarocladium strictum, and Plenodomus sp. In vitro analyses showed that Paraconiothyrium sp., Sarocladium kiliense, Acremonium curvulum, Setophoma terrestris, Dissoconium sp., and Cladosporium flabelliforme exhibited antagonistic activity against $S$. sclerotiorum, with percentages of growth inhibition ranging from 25 to 60 $(p<0.05)$. Paraconiothyrium sp. BBXE1 (60\%), BBPB4.1 (60\%), BCMT4.1 (54\%), and S. kiliense (54\%) showed the highest values of Antagonism Percentages (AP). Therefore, fungi with inhibitory activity against $S$. sclerotiorum such as Paraconiothyrium $\mathrm{sp}$. are naturally endophytic in Brachiaria grasses.

Keywords: Coniothyrium-like fungi, Urochloa, tropical forage grasses, antagonism, white mold

\section{Introduction}

Grass pastures are widely distributed in different regions of Brazil, and the success of their establishment depends on the use of robust forage species. Brachiaria (syn. Urochloa) species are among the most important forages for cattle feeding in the country, reflecting their adequate adaptation to different conditions (Valle et al., 2009).

The beneficial association of some agricultural grass species from temperate regions with vertically transmitted Clavicipitaceous fungal endophytes is a well stablished phenomenon (Saikkonen et al., 2006). This mutualism may protect plants against the growth of herbivore insects through the balance between antagonistic signaling pathways and increased availability of nutrients (Saikkonen et al., 2006, 2013). This type of symbiosis is not commonly observed in tropical grasses (Sánchez Márquez et al., 2012). Nevertheless, a large diversity of horizontally transmitted endophytic fungi in Poaceae species used for cattle feeding in tropical regions deserves further investigation (Rodrigues and Dias-Filho, 1996).

Grasses can be used for mulching or rotation with dicots to reduce disease inoculum, since they do not share the same range of pathogens (Gasparotto et al., 1982; Görgen et al., 2009, 2010). The white mold is one of these diseases, caused by Sclerotinia sclerotiorum. This pathogen has a wide host range, but it mainly affects dicotyledonous hosts, including important crops such as soybean, bean and cotton, causing water-soaked lesions that expand rapidly killing a large portion of the aerial plant tissues, which commonly become covered by the white mycelium of the pathogen (Bolton et al., 2006).

Management of white mold in soybean crop may include rotation/mulching with nonhost Poaceae and the combination with biological control, using for example Trichoderma harzianum (Görgen et al., 2009, 2010), a fungus reported as endophytic in Brachiaria grasses (Rodrigues and Dias-Filho, 1996; Kago et al., 2016). Thus, a plausible hypothesis is that fungal endophytes of Brachiaria, a nonhost of $S$. sclerotiorum (Görgen et al., 2009), may harbor species with antagonistic effects against this plant pathogen. Therefore, we investigated the diversity of fungal endophytes associated with several Brachiaria species in Brazil and evaluated in vitro antagonism of the isolates against $S$. sclerotiorum.

\section{Materials and Methods}

\section{Sampling Brachiaria plants}

Thirty-nine disease-free plants of different species and hybrids of Brachiaria were sampled: B. ruziziensis; $B$. decumbens cv. Basilisk; B. mutica cv. Angola; hybrid cv. Mulato I and cv. Mulato II; B. humidicola common, cv. Llanero and cv. Tupi; B. brizantha cv. Piatã, cv. Xaraés, and cv. Marandu, in which 11 were collected from pasture fields and 28 from experimental plots. The samples were collected during the rainy and dry seasons from Aug 2012 to Oct 2013 in the following locations: five at the Universidade Federal de Lavras (Lavras-MG, Bra- 
zil); seven at the Embrapa Amazônia Oriental (BelémPA, Brazil); eight at the Embrapa Gado de Corte (Campo Grande-MS, Brazil); 19 at the Embrapa Gado de Leite (Juiz de Fora-MG, Brazil) (Figure 1). Plants in vegetative stage were harvested at $10 \mathrm{~cm}$ above the ground using pruning shears, placed in plastic bags and refrigerated for approximately $48 \mathrm{~h}$ until isolation (6 to $10 \mathrm{Apr}$ ). A cool box was used to transport samples to the laboratory.

\section{Isolation of endophytic fungi from Brachiaria plants}

Defoliated stem samples were washed under tap water, cut into $10 \mathrm{~cm}$ fragments and placed in $50 \mathrm{~mL}$ sterile Falcon tubes. Surface disinfestation was done by successive washes with sterile distilled water (1 min), $96 \%$ ethanol ( $2 \mathrm{~min})$, sterile distilled water (1 $\mathrm{min}), 5 \%$ sodium hypochlorite ( $2 \mathrm{~min})$, and a final wash three times in sterile distilled water (1 $\mathrm{min})$. Stem pieces were dried on sterile filter paper and cut into smaller pieces $(0.5 \mathrm{~cm})$ using a sterile scalpel. Fifteen stem pieces per plant sample were seeded onto Petri dishes containing PDA medium (potato infusion-dextrose-agar) amended with cefotaxime $\left(0.25 \mathrm{~g} \mathrm{~L}^{-1}\right)$ incubated at $25^{\circ} \mathrm{C}$. To assess the efficiency of disinfestation, aliquots of final rinse water of $100 \mu \mathrm{L}$ were similarly seeded. Samples were examined daily and the endophytic fungi were individually transferred to new plates containing PDA/ cefotaxime plates for purification. Isolates were stored with the Castellani's method (Castellani, 1939) at $4{ }^{\circ} \mathrm{C}$ in sterile tubes containing $1 \mathrm{~mL}$ of sterile distilled water.

\section{ITS and 18S rDNA sequencing and molecular identification}

The molecular identification of fungal isolates was performed using DNA sequences of ITS and 18S rDNA (White et al., 1990). Mycelia were scraped from colo- nies on PDA using a sterile toothpick and total DNA was extracted using the Microbial DNA Isolation Kit (MO $\mathrm{BIO}$. Amplification reactions were performed in $30 \mu \mathrm{L}$ reaction volumes containing $15 \mu \mathrm{L}$ of kit, $12 \mu \mathrm{L}$ of $\mathrm{H}_{2} \mathrm{O}$, $10 \mathrm{pmol}$ of each forward and reverse primer, and $1 \mathrm{ng}$ of DNA. For ITS amplification, primers ITS1 (5' -TCCGTAGGTGAACCTGCGG-3') and ITS4 (5'- TCCTCCGCTTATTGATATGC-3') were used, and reaction conditions were: $95^{\circ} \mathrm{C}$ for $2 \mathrm{~min}$, followed by 35 cycles at $95^{\circ} \mathrm{C}$ for $1 \mathrm{~min}, 50^{\circ} \mathrm{C}$ for $1 \mathrm{~min}$, and $72^{\circ} \mathrm{C}$ for $1 \mathrm{~min}$, with a final extension at $72^{\circ} \mathrm{C}$ for $7 \mathrm{~min}$. To amplify the $18 \mathrm{~S}$ region, primers NS1 (5'-GTAGTCATATGCTTGTCTC-3') and NS6 (5'-GCATCACAGACCTGTTATTGCCTC-3') were used. Reactions were performed in a thermocycler at $94{ }^{\circ} \mathrm{C}$ for $1 \mathrm{~min}$, followed by 35 cycles at $94{ }^{\circ} \mathrm{C}$ for $35 \mathrm{~s}, 55^{\circ} \mathrm{C}$ for $50 \mathrm{~s}$, and $72{ }^{\circ} \mathrm{C}$ for $2 \mathrm{~min}$, with a final extension at $72{ }^{\circ} \mathrm{C}$ for $6 \mathrm{~min}$.

The amplification products were purified and sent to Macrogen (Seoul, South Korea) for Sanger sequencing. The sequences were edited using the SeqAssem 07/2008 software and then compared with sequences of reference strains deposited in international culture collections available in the GenBank database (National Center for Biotechnology Information - NCBI) (https://www. ncbi.nlm.nih.gov/) using the Basic Local Alignment Search Tool (BLAST) and identification was performed according to the identities found.

\section{Antifungal activity of isolated endophytic fungi against Sclerotinia sclerotiorum}

The evaluation of antifungal activity was adapted from Kelemu et al. (2001). The pathogenic strain UFLA44 of S. sclerotiorum used in this work was collected from common bean field cultivar Ouro Vermelho by Abreu and Souza (2015) in the municipally of Coimbra, state of Minas Gerais, Brazil. A small mycelial



Figure 1 - Brazilian map showing the states and sites where plants were sampled. The map was created on the QGIS software version 2.18 using the Geographic Coordinate Reference System and Datum SIRGAS2000 from data of Instituto Brasileiro de Geografia e Estatística (IBGE). 
fragment of the endophyte was placed on one side of a Petri dish (9 $\mathrm{cm}$ diameter) containing PDA and incubated for $7 \mathrm{~d}$ at $25^{\circ} \mathrm{C}$. Next, $5 \mathrm{~mm}$ colony fragment of $S$. sclerotiorum UFLA44 obtained from sclerotia germination was placed on the opposite side the plate containing the endophyte (Figures 4A, B), where the phytopathogen was inoculated after the endophytic fungi because of its higher growth rate. The plates were incubated at $25^{\circ} \mathrm{C}$ for additional $7 \mathrm{~d}$ and, at the end, the pathogen radial growth was the measured variable. This experiment was conducted in a completely randomized design with 225 experimental units: 74 endophytic fungi; phytopathogen alone, corresponding to the control (Figure 4C); with three replicates.

The Antagonism Percentage (AP) of j-esim replicate $(\mathrm{n}=3)$ and i-esim treatment was calculated according to the equation: $\mathrm{AP}_{\mathrm{ij}}=(\mathrm{DM}-\mathrm{dm}) / \mathrm{DM} \times 100$, in which DM $(\mathrm{cm})=$ diameter average of the $S$. sclerotiorum colony in the absence antagonist endophytic fungus and $\mathrm{dm}(\mathrm{cm})=$ diameter average of the $S$. sclerotiorum colony in dual culture with the antagonist endophytic fungus. Data were statistically evaluated by analysis of variance (ANOVA) and the means were compared using the Tukey test at $5 \%$ probability level in SISVAR statistical software (version 5.6). The standard error of the mean was calculated and presented with the respective data.

Endophytes that exhibited antagonism against $S$. sclerotiorum were used in a second experiment to verify whether the observed inhibition resulted from the production of volatile or nonvolatile compounds by the endophytic fungi in the culture medium. The same methodology described in the first experiment was adopted, however, a bipartite Petri dish that prevented contact between the colonies was used.

\section{Results and Discussion}

We isolated 74 endophytic fungi from 39 stem samples of Brachiaria spp. collected in three states of Brazil (Figure 2). The 28 samples from experimental plots yielded 48 isolates, while 26 isolates were recovered from 11 samples collected in pasture fields, an overall recovery rate of two isolates per sample.

Twenty-eight species of the endophytic fungi were identified by ITS and 18S rDNA sequences comparison, most belonging to Phylum Ascomycota (Figure 3A). Paraconiothyrium sp. was the most abundant endophyte (Figure $3 \mathrm{~B}$ ), accounting for $24 \%$ (14 isolates) of total and isolated from all samples, except for one sample (hybrid cv. Mulato II and B. mutica). Phoma sorghina (11 isolates) was the second most abundant taxon, followed by Sarocladium strictum, and Plenodomus sp., both taxa represented by seven isolates. These four species accounted for approximately two-thirds of all isolates $(68 \%)$, but corresponded to $32 \%$ of all species recovered.

Paraconiothyrium, Phoma, and Plenodomus are Pleosporales genera belonging to different families of the Dothideomycetes class. Taxonomy of this group coniothyrium-like fungi is quite complex and subjected to periodical updates, mainly to accommodate the wealth of DNA sequence data and phylogenetic reassessments of ex-type and other reference strains preserved in culture collections (Verkley et al., 2014; Ariyawansa et al., 2015; Chen et al., 2015). On the other hand, the ITS marker is generally reliable for strain typing and identifications to genus level among this group of fungi (Verkley et al., 2014). Species of Phoma-like fungi are common endophytes of grasses, such as the temperate species Dactylis glomerata and Holcus lanatus (Sánchez Márquez et al., 2007, 2010). Two putative Phoma species were reported

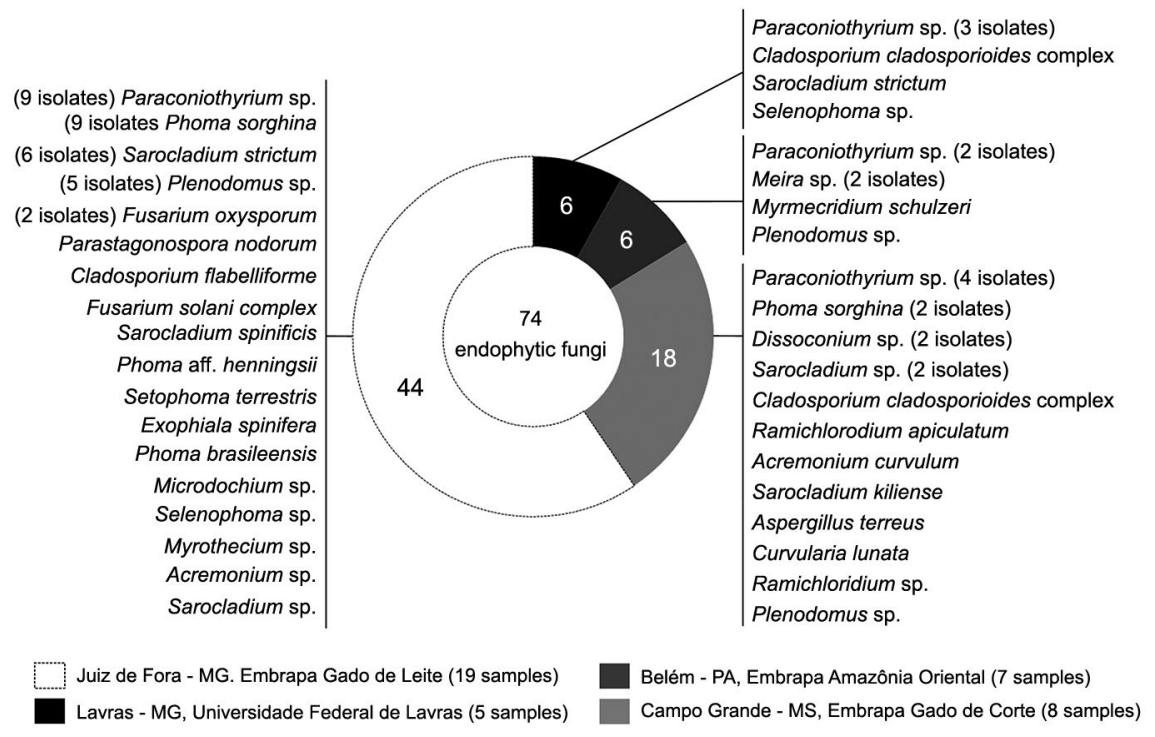

Figure 2 - Endophytic fungi isolated from different species of Brachiaria for each sampling site in Brazil. 


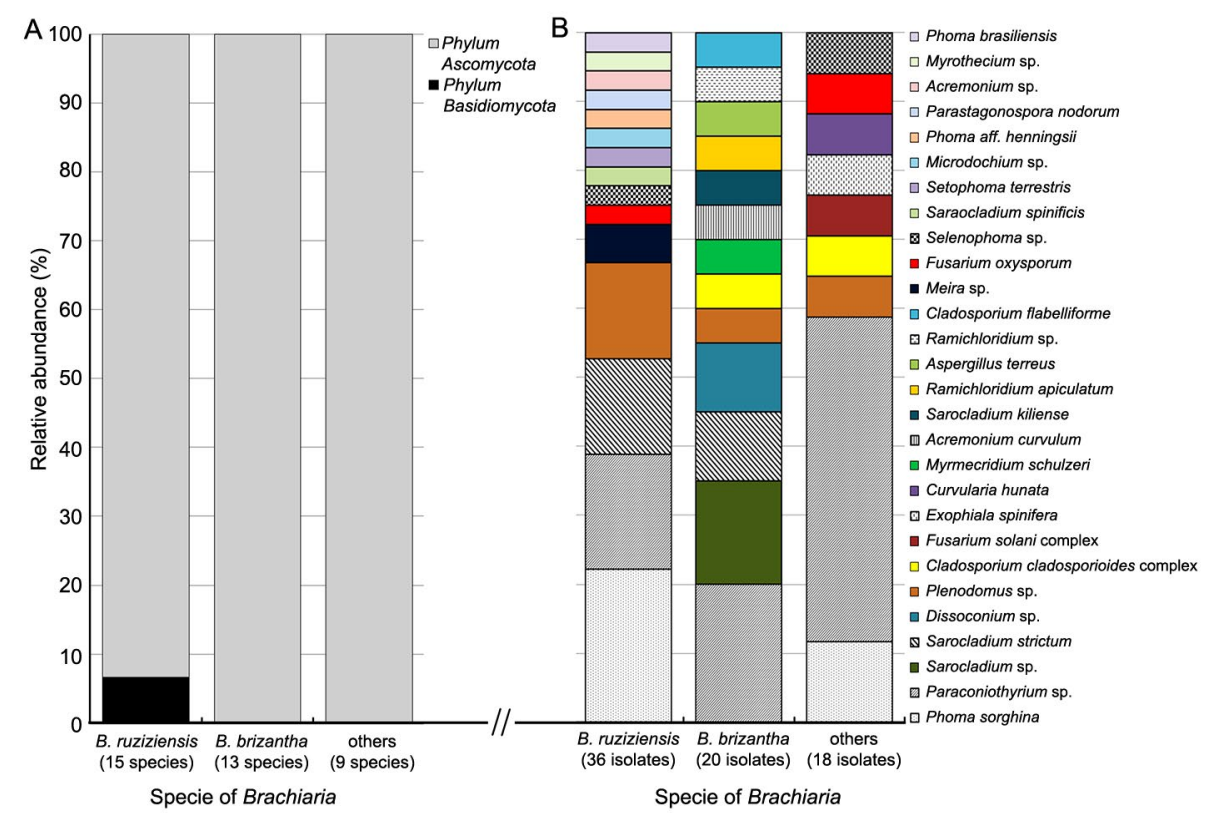

Figure 3 - Relative abundance at (A) phylum and (B) species level of endophytic fungi isolated from different species of Brachiaria.

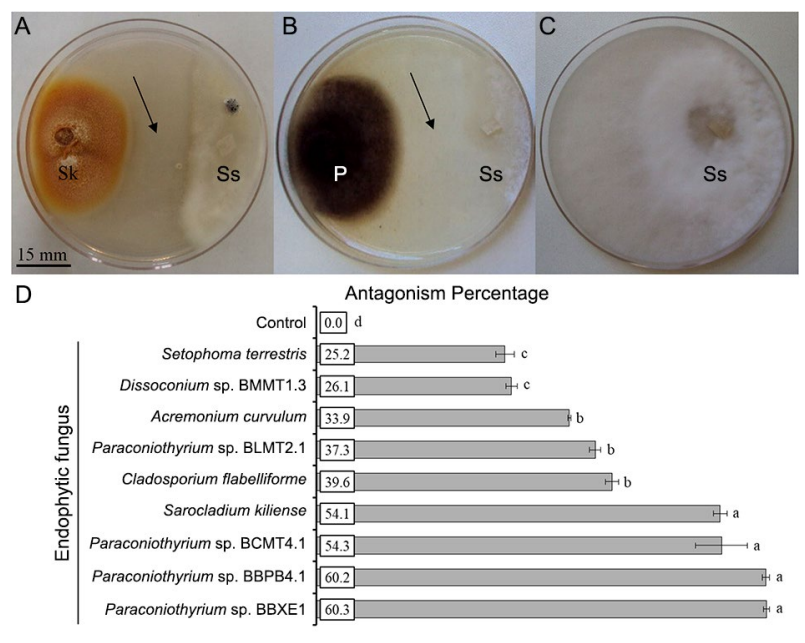

Figure 4 - (A) In vitro antagonism of Sarocladium kiliense (Sk) and (B) Paraconiothyrium sp. BBPB4.1 (P) in relation to Sclerotinia sclerotiorum (Ss) in dual cultures. (C) Growth of Ss after 7 days in the absence of antagonist. (D) Antagonism percentage values exhibited by selected endophytic fungi against Ss ( $<<0.05)$. Means followed by same letter do not differ by the Tukey test at $5 \%$ level $(n=3)$ and bars represent the standard error of the mean. Arrows in $(A)$ and $(B)$ show the inhibition zones.

as endophytes of Brachiaria in a preliminary inventory conducted in Brazil (Rodrigues and Dias-Filho, 1996). P. sorghina, the second most abundant species and isolated from $B$. ruziziensis, $B$. decumbens, and $B$. humidicola, was also one of the most frequently isolated endophyte in perennial grasses Hyparrhenia hirta and Bothriochloa ma- cra in Australia (White and Backhouse, 2007). Species of Paraconiothyrium were the dominant root endophytes of native grasses inhabiting semiarid grasslands in New Mexico (Khidir et al., 2010). We isolated endophytes from the lower part of plant stems and the root system of Brachiaria and the soil are possibly the source of the abundant Paraconiothyrium taxon, since this is a genus of common soil-borne fungi (Domsch et al., 2007).

Twelve isolates were identified as Sarocladium species, the third most common genus of Brachiaria endophytes. B. brizantha yielded Sarocladium sp., S. kiliense and $S$. strictum. From B. ruziziensis, $S$. spinificis and $S$. strictum were isolated. There is a high diversity of Sarocladium in grasses, mostly endophytes and some phytopathogens (e.g. S. oryzae). This diversity is shown by the description of two new species, Sarocladium spinificis, endophytic to coastal grass Spinifex littoreus in Taiwan, and S. brachiariae, recently described in B. brizantha China (Yeh and Kirschner, 2014; Liu et al., 2017). S. implicatum (formerly known as Acremonium implicatum) was identified as a seed-transmitted endophyte of Brachiaria species, where it may play a role in protecting plants against fungal pathogens, such as Drechslera spp., which causes leaf spots (Kelemu et al., 2001). Seedborne S. implicatum can colonize other plant parts after germination and provide fitness advantages to the host (Kago et al., 2016).

Two isolates of Meira sp. from B. ruziziensis were the sole representatives of Phylum Basidiomycota in this study. Species of this genus were described as acaropathogenic and can be found as endophyte of many plant species (Rush and Aime, 2013). Moreover, a recent study reported the isolation of Meira sp. as an endophyte of the temperate grass Ammophila arenaria (Sánchez Márquez et al., 2012). 
In vitro analyses showed that the endophytic fungi Paraconiothyrium sp. (isolates BLMT2.1, BCMT4.1, BBPB4.1, and BBXE1), Sarocladium kiliense, Acremonium curvulum, Setophoma terrestris, Dissoconium sp. (isolate BMMT1.3) and Cladosporium flabelliforme exhibited antagonistic activity against $S$. sclerotiorum $(p$ $<0.05)$, with percentages of growth inhibition ranging from 25 to 60 (Figure 4D). Paraconiothyrium sp. BBXE1, BBPB4.1, BCMT4.1, and S. kiliense showed the highest values of Antagonism Percentages.

The growth inhibition of $S$. sclerotiorum is not likely caused by the synthesis of volatile molecules, because no inhibition was observed when these fungi were grown in bipartite plates. Coniothyrium minitans is a known mycoparasite capable of controlling plant diseases caused by fungal pathogens, including $S$. sclerotiorum (Whipps et al., 2008), reducing survival of sclerotia and production of apothecia (Zeng et al., 2012). Almeida et al. (2014) reported the isolation of graminin B, a compound with antibiotic activity obtained from fermentation of broths of species $P$. hawaiensis. Three isolates of Paraconiothyrium sp. showed the highest inhibition rates in our bioassays (BBXE1, BBPB4.1, and BCMT4.1), suggesting that other Paraconiothyrium species can be used in the biocontrol of white mold and that antibiosis is another mode of action of them.

One endophytic isolate of $S$. kiliense reduced the growth of $S$. sclerotiorum by more than a half through the excretion of metabolites in the medium and formation of inhibition halo (Figure 4A). The bioactivity of secondary metabolites produced by Sarocladium species is well documented in the case of $S$. oryzae, a producer of the phytotoxic helvolic acid and the antifungal compound cerulenin (Hittalmani et al., 2016). Secondary metabolites produced by an endophytic isolate of $S$. implicatum from Brachiaria inhibited the growth of Rhizoctonia solani, causal agent of foliar blight in Brachiaria, and Pyricularia oryzae, causal agent of rice blast (Kelemu et al., 2001). Considering that in vitro antagonism does not always predict efficacy, in vivo studies are needed to confirm these considerations since they were based only on in vitro test.

In the management of white mold caused by $S$. sclerotiorum, one of the recommendations is crop rotation of the host-plant with Brachiaria spp. This strategy can be potentialized by the application of Trichoderma harzianum over grass litter prior to the next sowing of the host plant, increasing eradication effects on the pathogen initial inoculum (Görgen et al., 2009). Although no Trichoderma sp. was recovered from Brachiaria sp., abundant Paraconiothyrium spp. may offer a reliable disease control. Trichoderma spp. has limited performance under cooler temperatures (Paula Junior et al., 2012), the most favorable condition for S. sclerotiorum ascospore release and white mold epidemic outbreak (Bolton et al., 2006) as well as for C. minitans sclerotia parasitism (Whipps et al., 2008).
Once Brachiaria sp. harbors endophytic fungi, such as Paraconiothyrium sp. with inhibitory activity against $S$. sclerotiorum, rotation with Brachiaria sp. enriched with the antagonistic endophytic fungus may offer a package composed of two disease management tools by planting Brachiaria sp. This prospect should be explored in future in vivo studies with active application of endophytes to Brachiaria seeds or to the field. The bioactive compounds produced by these endophytic fungi also deserve further investigation, since they may be used in the control of plant diseases or other fields, such as medicine and industry.

\section{Conclusions}

Brachiaria spp. from different experimental plots and pasture fields in Brazil yielded 28 taxa of stem-associated endophytic fungi. Two-thirds of all isolates belong to four of the most common species, Paraconiothyrium sp., Phoma sorghina, Plenodomus sp., and Sarocladium strictum.

Four isolates of the most common endophytic fungus Paraconiothyrium sp. (BLMT2.1, BCMT4.1, BBPB4.1, and BBXE1) in addition to Sarocladium kiliense, Acremonium curvulum, Setophoma terrestris, Dissoconium sp. (isolate BMMT1.3), and Cladosporium flabelliforme exhibited in vitro antifungal activity against $S$. sclerotiorum. Tests with Brachiaria sp. enriched with the antagonistic endophytic fungus and the investigation of bioactive compounds produced should be explored in future studies.

\section{Acknowledgements}

To the Coordenação de Aperfeiçoamento de Pessoal de Nivel Superior (CAPES), for the scholarships granted to the first author; to the Fundação de Amparo à Pesquisa do Estado de Minas Gerais (FAPEMIG), for the financial support to this study (CAG-APQ-02100-13); to the researchers of the Universidade Federal de Lavras, Embrapa Gado de Corte, Embrapa Gado de Leite, and Embrapa Amazônia Oriental, for the providing the samples used in this work.

\section{Author's Contributions}

Conceptualization: Gama, D.S.; Medeiros, F.H.V.; Cardoso, P.G. Data acquisition: Gama, D.S.; Cardoso, P.G. Data analysis: Gama, D.S.; Santos, I.A.F.M. Design of methodology: Gama, D.S.; Medeiros, F.H.V.; Cardoso, P.G. Writing and editing: Gama, D.S.; Santos, I.A.F.M.; Abreu, L.M.; Medeiros, F.H.V.; Duarte, W.F; Cardoso, P.G.

\section{References}

Abreu, M.J.; Souza, E.A. 2015. Investigation of Sclerotinia sclerotiorum strains variability in Brazil. Genetics and Molecular Research 14: 6879-6896. 
Almeida, C.; Aouad, N.E.; Martín, J.; Pérez-Victoria, I.; GonzálezMenéndez, V.; Platas, G.; La Cruz, M.; Monteiro, M.C.; Pedro, N.; Bills, G.F.; Vicente, F.; Genilloud, O.; Reyes, F. 2014. Graminin B, a furanone from the fungus Paraconiothyrium sp. The Journal of Antibiotics 67: 421-423.

Ariyawansa, H.A.; Phukhamsakda, C.; Thambugala, K.M.; Bulgakov, T.S.; Wanasinghe, D.N.; Perera, R.H.; Mapook, A.; Camporesi, E.; Kang, J.; Jones, E.B.G.; Bahkali, A.H.; Jayasiri, S.C.; Hyde, K.D.; Liu, Z.; Bhat, J.D. 2015. Revision and phylogeny of Leptosphaeriaceae. Fungal Diversity 74: 19-51.

Bolton, M.D.; Thomma, B.P.H.J.; Nelson, B.D. 2006. Sclerotinia sclerotiorum (Lib.) de Bary: biology and molecular traits of a cosmopolitan pathogen. Molecular Plant Pathology 7: 1-16.

Castellani, A. 1939. Viability of some pathogenic fungi in distilled water. Journal of Tropical Medicine and Hygiene 42: 225226.

Chen, Q.; Jiang, J.R.; Zhang, G.Z.; Cai, L.; Crous, P.W. 2015. Resolving the Phoma enigma. Studies in Mycology 82: 137-127.

Domsch, K.H.; Gams, W.; Anderson, T-H. 2007. Compendium of Soil Fungi. 2ed. IHW-Verlag, Eching, Germany.

Gasparotto, L.; Chaves, G.M.; Condé, A.R. 1982. Survival of Sclerotinia sclerotiorum in soils cultivated with grasses. Fitopatologia Brasileira 7: 223-232 (in Portuguese, with abstract in English).

Görgen, C.A.; Civardi, E.A.; Ragagnin, V.A.; Silveira Neto, A.N.; Carneiro, L.C.; Lobo Junior, M. 2010. Reduction of Sclerotinia sclerotiorum initial inoculum in soybean grown after the use of the Santa Fé system. Pesquisa Agropecuária Brasileira 45: 1102-1108 (in Portuguese, with abstract in English).

Görgen, C.A.; Silveira Neto, A.N.; Carneiro, L.C.; Ragagnin, V.; Lobo Junior, M. 2009. White mold control with mulch and Trichoderma harzianum 1306 on soybean. Pesquisa Agropecuária Brasileira 44: 1583-1590.

Hittalmani, S.; Mahesh, H.B.; Mahadevaiah, C.; Prasannakumar, M.K. 2016. De novo genome assembly and annotation of rice sheath rot fungus Sarocladium oryzae reveals genes involved in Helvolic acid and Cerulenin biosynthesis pathways. BMC Genomics 17: 271.

Kago, L.; Njuguna, J.; Njarui, D.M.G.; Ghimire, S.R. 2016. Fungal endophyte communities of Brachiaria grass (Brachiaria spp.) in Kenya. p. 150-162. In: Njarui, D.M.G; Gichangi, E.M.; Ghimire, S.R.; Muinga, R.W., eds. Climate smart Brachiaria grasses for improving livestock production in East Africa Kenya Experience. Kenya Agricultural and Livestock Research Organization, Nairobi, Kenya.

Kelemu, S.; White Júnior, J.F.W.; Muñoz, F.; Takayama, Y. 2001. An endophyte of the tropical forage grass Brachiaria brizantha: isolating, identifying, and characterizing the fungus, and determining its antimycotic properties. Canadian Journal of Microbiology 47: 55-62.

Khidir, H.H.; Eudy, D.M.; Porras-Alfaro, A.; Herrera, J.; Natvig, D.O.; Sinsabaugh, R. 1. 2010. A general suite of fungal endophytes dominate the roots of two dominant grasses in a semiarid grassland. Journal of Arid Environments 74: 35-42.

Liu, X.B.; Guo, Z.K.; Huang, G.X. 2017. Sarocladium brachiariae sp. nov., an endophytic fungus isolated from Brachiaria brizantha. Mycosphere 8: 827-834.
Paula Júnior, T.J.; Teixeira, H.; Vieira, R.F.; Morandi, M.A.D.; Lehner, M.S.; Lima, R.C.; Carneiro, J.E.S. 2012. Limitations in controlling white mold on common beans with Trichoderma spp. at the fall-winter season. Summa Phytopathologica 38: 337-340.

Rodrigues, K.F.; Dias-Filho, M.B. 1996. Fungal endophytes in the tropical grasses Brachiaria brizantha cv. Marandu and $B$. humidicola. Pesquisa Agropecuária Brasileira 31: 905-909.

Rush, T.A.; Aime, M.C. 2013. The genus Meira: phylogenetic placement and description of a new species. Antonie van Leeuwenhoek 103: 1097-1106.

Saikkonen, K.; Gundel, P.E.; Helander, M. 2013. Chemical ecology mediated by fungal endophytes in grasses. Journal of Chemical Ecology 39: 962-968.

Saikkonen, K.; Lehtonen, P.; Helander, M.; Koricheva, J.; Faeth, S.H. 2006. Model systems in ecology: dissecting the endophytegrass literature. Trends in Plant Science 11: 428-433.

Sánchez Márquez, S.; Bills, G.F.; Herrero, N.; Zabalgogeazcoa, Í. 2007. The endophytic mycobiota of the grass Dactylis glomerata. Fungal Diversity 27: 171-195.

Sánchez Márquez, S.; Bills, G.F.; Herrero, N.; Zabalgogeazcoa, Î. 2010. Endophytic mycobiota of leaves and roots of the grass Holcus lanatus. Fungal Diversity 41: 115-123.

Sánchez Márquez, S.; Bills, G.F.; Herrero, N.; Zabalgogeazcoa, Í. 2012. Non-systemic fungal endophytes of grasses. Fungal Ecology 5: 289-297.

Valle, C.B.; Jank, L.; Resende, R.M.S. 2009. Tropical forage breeding in Brazil. Revista Ceres 56: 460-472 (in Portuguese, with abstract in English).

Verkley, G.J.M.; Dukik, K.; Renfurm, R.; Göker, M.; Stielow, J.B. 2014. Novel genera and species of coniothyrium-like fungi in Montagnulaceae (Ascomycota). Persoonia: Molecular Phylogeny and Evolution of Fungi 32: 25-51.

Whipps, L.M.; Sreenivasaprasad, S.; Muthumeenakshi, S.; Rogers, C.W.; Challen, M. P. 2008. Use of Coniothyrium minitans as a biocontrol agent and some molecular aspects of sclerotial mycoparasitism. European Journal of Plant Pathology 121: 323330.

White, L.R.; Backhouse, D. 2007. Comparison of fungal endophyte communities in the invasive panicoid grass Hyparrhenia hirta and the native grass Bothriochloa macra. Australian Journal of Botany 55: 178-185.

White, T.J.; Bruns, T.; Lee, S.; Taylor, J.W. 1990. Amplification and direct sequencing of fungal ribosomal RNA genes for phylogenetics. p. 315-322. In: Innis, M.A.; Gelfand, D.H.; Sninsky, J.J.; White, T.J., eds. PCR protocols: a guide to methods and applications. Academic Press, New York, NY, USA.

Yeh, Y-H.; Kirschner, R. 2014. Sarocladium spinificis, a new endophytic species from the coastal grass Spinifex littoreus in Taiwan. Botanical Studies 55: 25.

Zeng, W.; Wang, D.; Kirk, W.; Hao, J. 2012. Use of Coniothyrium minitans and other microorganisms for reducing Sclerotinia sclerotiorum. Biological Control 60: 225-232. 